\title{
Public Policy Failure: A Study of Home Industry Food Production Certification Policy
}

\author{
Hendri Koeswara, Desna Aromatica, Malse Yulivestra, Muhammad Ichsan Kabullah, Roza Liesmana
}

Universitas Andalas, Padang, Indonesia

\begin{tabular}{|c|c|}
\hline ARTICLE INFORMATION & A B S T R A C T \\
\hline $\begin{array}{l}\text { Received: July 26, } 2021 \\
\text { Revised: September 14, } 2021 \\
\text { Accepted: October } 25,2021 \\
\text { Available online: October 31, } 2021\end{array}$ & \multirow{4}{*}{$\begin{array}{l}\text { There is an increasing concentration of Public Administration scientists on measuring whether policy succeeds } \\
\text { or fails. It is no longer clear how best to ensure that the policy process from formulation to policy implementation } \\
\text { is the best and more effective way. Including in the Home Industry Food, Production Certificate Policy (SPP- } \\
\text { IRT) is taken as a locus. Study of the Home Industry of Ground Coffee in Nagari Koto Tuo, Tanah Datar } \\
\text { Regency. The policy on offering SPP-IRT has undergone several changes, but it will not be effective. It will fail to } \\
\text { provide quality assurance and food safety. the increase in IRTPs who have certificates does not increase. The } \\
\text { research method used in this study uses a qualitative approach with a case study research design. The results } \\
\text { showed that providing Food Home Industry Certification (IRTP) with the case in the provision of IRTP Coffee } \\
\text { Powder certificates in Nagari Koto Tuo showed that the policy failures included tolerable policy criteria. } \\
\text { Modest loss when it happens does not fundamentally hold back the goals the proponents want to achieve, and the } \\
\text { minor opposition and criticism that occurs is almost non-existent in this SPP-IRT-related policy. }\end{array}$} \\
\hline KEYWORDS & \\
\hline policy failure, certification policy, public policy & \\
\hline CORRESPONDENCE & \\
\hline
\end{tabular}

\section{PENDAHULUAN}

Industri rumah tangga sangat banyak berkembang di Indonesia, malah menjadi penopang utama ekonomi bagi sebagian masyarakat. Bahkan pada saat krisis ekonomi 1998 lalu, industri rumah tangga telah menjadi benteng ekonomi masyarakat (Sarfiah, Atmaja, \&e Verawati, 2019). Ironisnya, sanitasi dan keamanan pangannya yang merupakan salah satu aspek penting dalam Industri Rumah Tangga Pangan (IRTP) menjadi sering terlupakan. Padahal, keamanan pangan dan pangan yang bergizi merupakan salah satu hak yang mesti diakui karena penting bagi kesehatan manusia, hal ini sesuai dengan amanat Undang-Undang Nomor 8 Tahun 1999 tentang Perlindungan Konsumen, Undang-Undang Nomor 36 Tahun 2009 tentang Kesehatan, dan Undang-Undang Nomor 18 Tahun 2012 tentang Pangan. Menyikapi kebijakan tersebut, Badan Pengawas Obat dan Makanan (BPOM) RI mengeluarkan Peraturan Kepala Badan Pengawas Obat dan Makanan (BPOM) Nomor HK.03.1.23.04.12.2206 Tahun 2012 tentang Cara Produksi Pangan Olahan yang Baik (CPPOB) untuk UMKM/IRTP. Hal tersebut merupakan strategi kebijakan yang dilakukan oleh pemerintah dalam peningkatan mutu dan keamanan pangan, sehingga produk benar-benar aman untuk dikonsumsi. Dalam regulasi tersebut terdapat juga atribut yang tentang bagaimana tata cara yang baik dalam produksi pangan, yang diawali dengan bahan baku produk sampai menjadi produk jadi, kesiapan dalam pendistribusian, dan persyaratanpersyaratan lain yang dibutuhkan (Owen et al., 2020).

Krisis kesehatan yang terjadi dari kategori bencana menempatkan Bencana Non Alam sebesar 42,6\%. Tingginya angka tersebut adalah cerminan dari pelbagai regulasi terkait kesehatan dan keamanaan pangan tidak terimplementasi dengan baik. Dari persentase tersebut diketahui bahwa Kejadian Luar Biasa (KLB) dari Keracunan Makanan adalah sebesar 16,8\% (Kementerian Kesehatan, 2020). Sementara berdasarkan data dari BPOM RI (2020) KLB Keracunan Pangan (KP) terdapat 77 (tujuh puluh tujuh) KLB KP dimana terdapat 7244 orang terpapar. Dan, dari data tersebut sebanyak 3281 orang mengalami gejala sakit (attack rate sebesar 45,29\%). Lalu, terdapat 5 (lima) orang korban yang meninggal dunia (case fatality rate sebesar 0,07\%). Dapat diakui bahwa data ini masih jauh dari fakta kejadian sebenarnya, karena tidak semua kasus atau kejadian terlaporkan. Artinya bahwa isu kesehatan dan pangan ini menjadi prioritas untuk dituntaskan baik dari sisi penanganan maupun regulasi. Berikut pada gambar 1 disajikan data tentang persentase bencana non alam

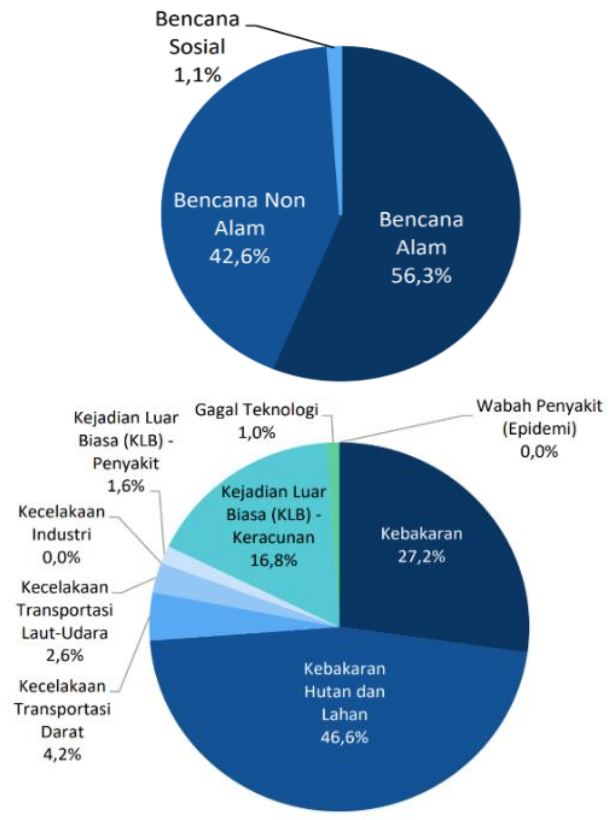

Gambar 1. Persentase Bencana Non Alam Sumber: Profil Kesehatan Indonesia Tahun 2019 (Kemenkes, 2020) 
BPOM RI pun telah mengeluarkan juga instrument kebijakan lanjutan untuk pangan sehat dan aman melalui Peraturan Kepala BPOM RI Nomor 22 Tahun 2018 tentang Pedoman Pemberian Sertifikat Produksi Pangan Industri Rumah Tangga (SPP-IRT). SPP-IRT ini merupakan sertifikat yang wajib dimiliki oleh PIRT (Pangan Industri Rumah Tangga). Regulasi tersebut mengatur tentang pemberian izin bagi IRTP yang merupakan perusahaan pangan yang memiliki tempat usaha di tempat tinggal dengan peralatan pengolahan pangan manual hingga semi otomatis (Perka BPOM No 22/2018). Sementara Pangan Produksi IRTP adalah pangan olahan hasil produksi IRTP yang diedarkan dalam kemasan dan eceran dan berlabel. Lalu, produksi pangan merupakan kegiatan atau proses dalam menghasilkan, menyiapkan, mengolah, membuat, mengawetkan, mengolah, membuat, mengawetkan, mengemas kembali, dan atau mengubah bentuk. Berkaitan dengan hal tersebut, kebijakan tentang Pedoman Pengawasan Pangan Industri Rumah Tangga BPOM juga telah dikeluarkan oleh BPOM melalui Peraturan Kepala BPOM RI Nomor 23 Tahun 2018 untuk memastikan fungsi pengawasan terhadap PIRT yang ada juga dapat dilakukan dengan efektif. Kebijakan ini merupakan implikasi terhadap adanya kebijakan pemerintah dalam hal ini telah diatur dalam Peraturan Pemerintah Nomor 28 Tahun 2004 tentang Keamanan, Mutu, dan Gizi Pangan. Kebijakan ini merupakan pedoman bagi tenaga pengawas pangan (District Food Inspector) pada pemerintah daerah untuk mengawasi pangan produk IRTP dalam perlindungan terhadap konsumen dalam hal keamanan pangan yang tidak memenuhi persyaratan pangan dan keamanan terhadap pangan yang telah dipalsukan (food fraud).

Konsekuensi logis dari pelbagai regulasi yang dikeluarkan oleh BPOM, Dinas Kesehatan di masing-masing lingkup wilayah IRTP harus memfasilitasi seluruh pelaku industri pangan rumah tangga untuk memiliki izin dan Sertifikat PIRT. Akan tetapi pelbagai kebijakan dalam peningkatan mutu dan jaminan atas keamanan pangan seperti menemui jalan buntu. Pemberian SPP-IRT yang difasilitasi oleh Dinas Kesehatan di daerah, seperti temuan penelitian sebelumnya yang dilakukan oleh Koeswara, dkk (2020) di Nagari Koto Tuo menunjukkan bahwa masih minimnya jumlah PIRT Kopi Bubuk di Koto Tuo yang memiliki SPP-IRT. Dari sebanyak 177 merk dagang Kopi Bubuk atau sekitar 160 IRTP yang ada, hanya 12,42\% (22) yang sudah memiliki izin PIRT pada Tahun 2020. Walaupun angka ini meningkat dari tahun sebelumnya yaitu sebanyak 13 (tiga belas) SPP-IRTP pada Tahun 2018 dan 17 (tujuh belas) SPPIRTP pada Tahun 2019. Tren peningkatannya tidak signifikan, jika dibandingkan dengan jumlah PIRT yang ada, angka ini sangat kecil sekali.

Berbagai kajian menyebutkan bahwa sisi kelemahan dalam implementasi kebijakan pemberian SPP-IRT ini kerap terjadi karena ketidakmampuan dan lemahnya kesadaran IRTP dalam memenuhi persyaratan permohonan SPP-IRTP, seperti kajian evaluasi kebijakan yang dilakukan oleh Ardiati \& Puspikawati (2019). Tapi belum ada yang mengkaji lemahnya implementasi kebijakan tersebut dari sisi pembuat atau implementor kebijakannya atau dari kebijakannya sendiri yang tidak implementatif, yang mengakibatkan kegagalan karena pembuat kebijakan berharap terlalu optimis bahwa kebijakan yang dihasilkannya akan terimplementasi dengan baik (Hudson, Hunter, \& Peckham, 2019). Agaknya inilah argumentasi yang lebih tepat bahwa sebetulnya kebijakan ini terlalu sulit untuk terimplementasi dengan sukses, karena rumitnya persyaratan yang diminta untuk pengurusan Sertifikat IRTP ini bagi IRTP di Koto Tuo. Situasi ini, jika dilihat dari konsep yang diusung oleh McConnell (2015) bahwa kegagalan kebijakan merupakan keberhasilan yang dicapai secara minimal, tujuan kebijakan secara fundamental tidak dapat dicapai, dan kebijakan tersebut mendapat dukungan yang kurang optimal. Jika ditelaah lebih jauh kegagalan kebijakan pemberian SPP-IRT ini dapat diidentifikasi dalam derajat kegagalan, yaitu: proses, program, dan politik, dan inilah yang akan diurai dalam penelitian ini. Sedangkan konsep kegagalan implementasi merujuk pada resiko kegagalan kebijakan juga terjadi karena faktor implementasi (bad execution), kebijakan yang tidak bagus (bad policy), dan kebijakan yang bernasib buruk (bad luck) sebagaimana yang diungkap oleh Hogwood, Brian W., \& Gunn (1986). Beberapa perspektif inilah yang akan membantu penulis dalam mengurai kebijakan SPP-IRT dalam tulisan ini.

Kajian tentang SPP-IRT, telah banyak dikaji oleh banyak peneliti, tetapi penulis berkeyakinan bahwa belum banyak penulis yang mengurai dari perspektif kegagalan kebijakan. Seperti kajian yang dilakukan Kurniawan \& Astuti (2018) yang lebih memilih berfokus pada pendampingan pengurusan IRTP yang dilakukan oleh. Sementara itu, Komala, I'ik Santi, Widajanti, Laksi, \& Pangestuti (2017) mengkaji tentang cara produksi pangan yang baik untuk PIRT. Perspektif komunikasi dalam label IRTP juga tak luput dari kajian ilmuwan, seperti yang dilakukan oleh Fitriah, M., \& Kusumadinata (2017) tentang informasi label kemasan produk IRTP. Lalu, kajian tentang efektivitas program peningkatan mutu pangan dan jaminan keamanan pangan IRTP diteliti oleh Purba, Nuraida, \& Koswara (2013). Kajian lain juga tak kalah menariknya adalah tentang pemanfaatan teknologi bagi IRTP seperti yang ditelaah oleh Boedirochminarni, Wachid, \& Anggraini (2009). Berbeda dengan Murwadji \& Saraswati (2019) mereka lebih memilih untuk mengkaji tentang penguatan kapasitas IRTP melalui sertifikasi produk pangan IRT. Sementara Rohmah, Domai, Publik, Administrasi, \& Brawijaya (2015) melakukan penelitian tentang strategi pengembangan IRTP. Sedangkan kajian tentang IRTP dari perspektif kebijakan juga telah banyak dikaji seperti Hermanu (2016) dari perspektif implementasi, Ardiati \& Puspikawati (2019), Owen et al. (2020), Putri, Rr. Asri Ismaya., Rohayati, Yati., \& Aisha (2015), dan Rezki (2020) dari perspektif evaluasi. Sementara kajian yang dilakukan oleh penulis adalah dengan pendekatan yang digunakan oleh McConnell (2015) untuk menelaah kegagalan kebijakan penulis jadikan untuk meretas tentang kegagalan kebijakan publik dalam implementasi kebijakan pemberian Sertifikat Produksi Pangan Industri Rumah Tangga dengan mengambil studi pada fasilitasi pembuatan SPP-IRT di Nagari Koto Tuo.

\section{METODE}

Identifikasi terhadap tujuan dan sasaran kebijakan, respon kebijakan pemerintah terhadap pemberian sertifikat IRTP, dan kemampuan pemerintah dalam memfasilitasi IRTP menjadi sangat penting untuk menjamin kesehatan, aman, dan bergizinya pangan serta meminimalisir KLB yang angkanya cukup signifikan dalam bencana non alam yang terjadi merupakan keniscayaan yang harus dilakukan oleh pemerintah. Kajian tentang kegagalan kebijakan Sertifikasi Pangan Industri Rumah Tangga ini menggunakan metode penelitian kualitatif 
dengan mengurai derajat kegagalan kebijakan pada aspek proses, program, dan politik. Kajian ini berfokus pada substansi pemberian sertifikat SPP-IRT dari perspektif kegagalan kebijakan, dimana program dirancang untuk memenuhi tujuan dan terdapat intervensi yang tepat kepada masyarakat.

Untuk itu kajian penelitian tentang kegagalan kebijakan publik dalam implementasi kebijakan pemberian Sertifikat Produksi Pangan Industri Rumah Tangga ini menggunakan pendekatan penelitian deskriptif kualitatif dengan disain studi kasus sebagaimana yang dikemukakan oleh Yin (2008). Sebagai sebuah kajian penelitian studi kasus, tidak harus dalam waktu lama dan tidak tergantung pada data etnografi atau observasi partisipan. Bahkan menurut hujah Yin penelitian dalam menggunakan studi kasus dalam kajiannya bisa dengan studi kepustaan sesuai dengan topik kajiannya untuk mendapatkan hasil penelitian yang valid dan berkualitas tinggi. Kajian penelitian dengan pendekatan studi kasus dalam penelitian kualitatif juga dapat melakukan generalisasi pada sejumlah teori yang lebih luas. Generalisasi ini dapat dilakukan oleh peneliti ketika mengkaji kasus-kasus tambahan dan melakukan generalisasi hasil penelitian sebelumnya dengan menggunakan pada kasus yang baru. Sehingga, berdasarkan hujah inilah penulis berkeyakinan bahwa pendekatan ini sesuai dengan topik riset yang penulis lakukan.

Pada kajian penelitian ini, penulis menggunakan teori yang dikemukakan oleh McConnell tentang derajat kegagalan kebijakan sebagai poin akhir penelitian. Penelitian ini dilakukan dengan cara induktif, dimana data-data mulai dicari dan dikumpulkan, mengidentifikasi tema-tema umum, lalu sampai kepada teori atau model tertentu sebagaimana yang diungkap oleh Creswell (2013) dalam langkah-langkah analisis dalam penelitian kualitatif. Data yang digunakan dalam kajian ini didapat melalui wawancara, dokumentasi dan observasi. Wawancara dan observasi dilakukan ke semua para pihak dan sentra produksi kopi Bubuk di Koto Tuo, Dinas Kesehatan dan Dinas Koperasi dan UMKM Kabupaten Tanah Datar, BBPOM di Padang, BPOM RI. Sedangkan studi dokumentasi adalah semua kebijakan, peraturan, SOP, dan rekapitulasi terkait pemberian SPP-IRT di Kabupaten Tanah Datar. Semua data tersebut pada akhirnya dilakukan interpretasi atau pemaknaan data untuk menjelaskan hasil temuan penelitian kebijakan pemberian SPP-IRT ini, dengan terlebih dahulu melakukan membaca keseluruhan data dan melakukan analisis terhadap data hasil wawancara, observasi, dan studi dokumentasi, serta melakukan analisis dan disajikan dalam bentuk deskripsi dan narasi yang argumentatif tentang kebijakan pemerintah dalam implementasi kebijakan pemberian Sertifikat Produksi Pangan Industri Rumah Tangga dengan mengambil Studi pada Pemberian SPP-IRT di Nagari Koto Tuo Kabupaten Tanah Datar Provinsi Sumatera Barat.

\section{HASIL DAN PEMBAHASAN}

Kebijakan Publik merupakan proses politik yang amat kompleks dan analitis, tidak mengenal saat dimulai dan diakhirinya, dan batas-batas dari proses itu sesungguhnya yang paling tidak pasti (Lindblom, 1986). Berdasarkan pandangan tersebut, dalam hal kebijakan sertifikasi IRTP ini, pemerintah mesti menyadari bahwa sudah keniscayaan sebuah kebijakan yang dihasilkan tidak serta merta selesai dengan keluarnya kebijakan tersebut. Disamping itu, kebijakan akan selalu dihadapkan kesenjangan antara ekspektasi yang diharapkan oleh aktor dalam kebijakan dalam rumusan kebijakan yang dihasilkan dengan realitas kenyataan yang terjadi, dan hal yang seringkali tidak terhindarkan adalah sebuah kegagalan dalam kebijakan, akan tetapi berhasil dalam hal lain. McConnell (2015) mengemukakan apa yang disebut sebagai "maze of policy failure" yang lebih menjelaskan hal yang merupakan kegagalan dalam sebuah kebijakan publik. Pendapat McConnell dalam mengidentifikasi kegagalan dalam artian "kegagalan pemerintah dalam melakukan hal yang telah dipilih sebagai sebuah tindakan kebijakan yang telah dirumuskan" dalam pengertian kebijakan publik adalah apapun yang pemerintah pilih untuk melakukan atau tidak melakukan sebuah tindakan. Terdapat 3 (tiga) jenis "melakukan/tindakan" yang dimaksudkan oleh McConnell dalam konsep yang dikeluarkan, yaitu proses, program dan politik.

Sementara itu, McConnell juga membuat derajat kegagalan, yang dihasilkan berdasarkan hasil analisis dari masing-masing kriteria akan menghasilkan derajat kegagalan yang dikelompokkan oleh McConnell dalam 3 (tiga) tingkatan, yaitu: 1) Kegagalan yang dapat ditoleransi (Tolerable Failure): merupakan kegagalan kebijakan ketika tidak secara fundamental menghalangi pencapaian tujuan yang ingin dicapai oleh para pendukung, oposisi yang ada dalam jumlah yang kecil dan kritik hampir tidak ada sedikitpun; 2) Kegagalan Konflik (Conflicted Failure): yaitu kegagalan dalam mencapai tujuan cukup berimbang dengan usaha yang dilakukan dalam pencapaian tujuan, terdapat kritik yang cukup kuat, dan pertahanan yang cukup mumpuni. Pada intinya, kegagalan yang diakibatkan konflik tersebut diatasi oleh kontroversi berkala yang tidak pernah cukup sebagai pukulan fatal bagi kebijakan tersebut, tetapi tidak cukup untuk secara serius merusak para pembela HAM; dan 3) Kegagalan Langsung (Outright Failure): suatu kebijakan gagal, hanya berhasil dalam beberapa hal yang bersifat minimum, secara fundamental tidak mencapai tujuan yang ditetapkan oleh para pendukung, jumlah oposisi dalam porsi yang cukup besar dan hampir dapat dikatakan tidak terdapat dukungan. Kegagalan yang terjadi lebih besar daripada kesuksesan yang didapatkan dalam kewajiban politik. Dengan derajat kegagalan inilah penulis akan menjastifikasi kegagalan yang terjadi dalam Kebijakan Sertifikasi Produksi Pangan Industri Rumah Tangga.

Kebijakan Sertifikasi Produksi Pangan Industri Rumah Tangga atau biasa disebut Sertifikat IRTP ini, pemerintah diberikan kesempatan untuk "melakukan" seperti yang diungkap McConnell. Kebijakan pemberian SPP-IRT ini diatur melalui Peraturan Badan Pengawas Obat dan Makanan Nomor 22 Tahun 2018 tentang Pedoman Pemberian Sertifikasi Produksi Pangan Industri Rumah Tangga. Tidak terdapat perbedaan tujuan dari regulasi yang merupakan pengganti kebijakan sebelumnya yaitu Peraturan Kepala Badan Pengawas Obat dan Makanan Nomor HK.03.1.23.04.12.2205 Tahun 2012 tentang Pedoman Pemberian Sertifikat Produksi Pangan Industri Rumah Tangga. Kebijakan tentang sertifikasi IRTP ini, dalam Undang-Undang Nomor 23 Tahun 2014 menjelaskan kewenangan Pemerintah Kabupaten/Kota dalam menerbitkan izin produksi makanan dan minuman yang diproduksi oleh IRTP dan melakukan pengawasan post-market terhadap produk yang dihasilkan. Artinya, sudah terdapat pelimpahan kewenangan yang dilakukan oleh pemerintah kepada pemerintah kabupaten/kota dalam mengeluarkan sertifikat IRTP, termasuk bagi IRTP Kopi Bubuk di Koto Tuo. Sehingga 
regulasi ini merupakan pedoman bagi pemerintah kabupaten/kota melalui perangkat daerah terkait yang bertugas untuk melakukan tugas ini. Berdasarkan pedoman yang diberikan oleh BPOM RI, di Pemerintah Kabupaten Tanah Datar, tidak mempunyai langkah yang berbeda dengan yang diatur dalam regulasi. Terdapat tahapan dalam pemberian SPPIRT, yang dapat dilihat pada gambar 2 berikut:

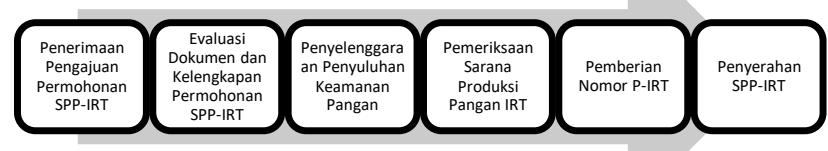

Gambar 2. Prosedur Penerbitan SPP-IRT

Sumber: Diolah dari PerbadanPOM RI No. 22/2018, 2021.

Dinas Kesehatan Kabupaten Tanah Datar telah melakukan prosedur sesuai dengan pedoman yang diatur melalui Peraturan Badan Pengawas Obat dan Makanan Nomor 22 Tahun 2018. Tidak ada klausul keringanan atau mencoba untuk menurunkan atau menghilangkan standar dalam persyaratan pengurusan sertifikat untuk mendapatkan SPP-IRT ini, termasuk dalam memberikan SPP-IRT bagi IRTP Kopi Bubuk di Nagari Koto Tuo. Padahal, sebanyak 177 merk dagang dan 160 IRTP pada Tahun 2021 yang lalu hanya tersertifikasi sebanyak 22 IRTP (12,42\%). Hal ini tentu idealnya menjadi bahan evaluasi bagi regulator karena dari sisi dukungan target sasaran dapat dikatakan sangat minim padahal jelas McConnell (2015) mengatakan bahwa dukungan dari kelompok sasaran merupakan hal yang penting dalam kebijakan.

Langkah Penyelenggaraan Penyuluhan Keamanan Pangan (PKP) sebagai salah satu tahapan dalam pengurusan SPP IRT, juga menghadapi masalahan besar karena mesti menunggu ketersediaan anggaran dari Pemerintah Kabupaten. Di sisi yang lain anggaran yang dimemiliki kemampuan yang terbatas dan juga mesti berbagi dengan jenis IRTP yang lain. BPOM RI dalam hal ini BBPOM di Padang keterlibatannya hanya sebagai narasumber pada Penyelenggaraan PKP tersebut, dan menyediakan fasilitas pengujian produk jika dibutuhkan. Sedangkan untuk menyelenggaraan Penyuluhan PKP sepenuhnya adalah tugas dan kewenangan Pemerintah Kabupaten. Langkah selanjutnya yang juga tidak terimplementasi dengan baik dan sering menjadi kendala adalah pada saat pemeriksaan Sarana Produksi Pangan IRT. Hasil observasi menunjukkan bahwa dalam proses produksi banyak dari IRTP dalam proses produksi memanfaatkan jasa huller baik untuk perendangan maupun penggilingan kopi bubuk yang mereka produksi. Hal inilah yang membuat IRTP di Koto Tuo selalu tidak lolos jangankan untuk sampai pada tahap pemeriksaan sarana, pada tahap screening berkas pengajuan mereka sudah mengalami penolakan. Sementara itu, peluang bisnis usaha huller ini cukup berkembang, berdasarkan hasil wawancara dengan salah satu pemilik hampir 10 (sepuluh) ton kopi direndang dan digiling serta diproses disini setiap minggunya. Dan jumlah heller ini semakin bertambah sepanjang tahun. Hasil pengamatan yang dilakukan, penulis juga menemukan bahwa tidak saja IRTP yang belum bersertifikat yang memanfaatkan jasa ini huller ini, ternyata ada beberapa IRTP yang sudah memiliki SPP-IRT pun jika menggunakan jasa huller ini. Hal ini juga menunjukkan bahwa sistem pengawasan keamanan pangan belum efektif. Disisi lain, mesti ada penyesuaian regulasi yang untuk hal ini yang belum terkomodir selama ini dalam kebijakan yang ada.

Kondisi ini sudah sepenuhnya disadari oleh masing-masing pemangku kepentingan, baik implementor dalam hal ini Dinas Kesehatan, Pemerintah Nagari, maupun BBPOM di Padang sendiri. Akan tetapi, tidak ada upaya untuk melakukan fasilitasi mencari solusi permasalahan agar fungsi pemerintah dalam menjamin kesehatan dan keamanan pangan tetap berjalan. Dan, disisi lain pengolahan pangan yang higienis tetap terus dilakukan sebagai kewajiban dalam meningkatkan daya saing produk pangan IRTP melalui peningkatan kesadaran dan motivasi produsen. Dalam perspektif kolaboratif, sangat tepat sekali digunakan konsep dimana regulator sekaligus adalah pelayan publik juga (Rosenbloom, David H., Kravchuk, Robert S., \& Clerkin, 2015). Tetapi dalam konteks ini, kebijakan sebagai proses menurut McConnell (2015) dalam menghasilkan keputusan kebijakan pemerintah gagal mencapai tujuan yang dimaksudkan, kemitraan dalam internal pemerintah sendiri menghadapi kendala. Pemerintah belum mampu untuk mengambil inisiatif kebijakan tertentu, misalnya dengan mendorong sertifikasi huller atau memberikan kriteria tertentu sebagai salah satu rantai produksi melalui Dinas Koperasi dan Perdagangan, padahal proses tersebut dimungkinkan ketika dikonfirmasi ke BPOM RI sebagai regulator. Oleh karena itu, dapat dikatakan bahwa kegagalan perumusan kebijakan dapat terjadi ketika aktor dalam perumusan kebijakan dalam pelbagai level yang berbeda tidak dapat mengubah jenis kebijakan yang sesuai dengan yang mereka harapkan, karena dianggap sebagai proses yang tidak sesuai dengan prosedur yang berlaku, hal inilah yang sesungguhnya terjadi pada kebijakan sertifikasi IRTP di Tanah Datar.

Menilik pada situasi yang saat ini masyarakat semakin peduli dan mempunyai kesadaran yang cukup meningkat akan pentingnya arti Kesehatan terhadap produk IRTP yang terdapat di pasaran termasuk didalamnya produk kopi bubuk yang ditawarkan oleh IRTP sekarang ini baik dari sisi produksi, pemasaran, maupun penyajian. Sehingga merupakan keniscayaan bahwa tuntutan masyarakat terhadap IRTP yang sehat dan aman untuk dikonsumsi merupakan tanggungjawab yang harus dipikul oleh pemerintah, apalagi masih tingginya KLB-KP yang terjadi pada Tahun 2019 yang lalu. Dari sisi kebijakan sebagai sebuah program, sebagaimana yang diungkap oleh McConnell (2015) sebagai luaran kebijakan, mesti diukur sejauhmana implementasi kebijakan sesuai dengan tujuan, hasil yang dicapai, menguntungkan atau tidak terhadap kelompok sasaran, memuaskan dari sisi kebijakan yang dikeluarkan (efisiensi anggaran), dan juga terdapat banyak dukungan terhadap tujuan program sertifikasi IRTP ini. Apa yang terjadi dengan kegagalan Pemerintah dalam memastikan bahwa produk IRT di Nagari Koto Tuo ini dari sisi keamanan pangan belum optimal dilakukan oleh pemerintah, masih banyak produk IRTP yang beredar di masyarakat yang tidak mampu dicakup oleh kebijakan yang dikeluarkan oleh pemerintah.

Implementasi kebijakan sertifikasi SPP-IRT hampir selama 12 (dua belas) tahun dijalankan dengan beberapa perubahan kebijakan yang ada. Tetapi efektivitas kebijakannya tidak terlihat mumpuni, salah satu indikasinya tentu angka KLB-PK yang masih tinggi. Program-program terkait SPP-IRT idealnya dirancang dalam upaya pencapaian tujuan dari kebijakan. Dan, hal tersebut mestilah didukung oleh asumsi bahwa intervensi 
yang dilakukan oleh pemerintah harus tepat dalam persoalan yang dihadapi oleh publik. Intervensi tersebut dapat berupa instrumen kebijakan seperti pemberian insentif dan maupun disinsentif, serta dapat juga berupa regulasi yang mengatur bagaimana perilaku yang harus ditunjukkan oleh publik dalam hal kepatuhan terhadap regulasi yang ada. Dalam hal pengawasan IRTP misalnya baru tahun ini (Tahun Anggaran 2021) pemerintah memberikan Dana Alokasi Khusus (DAK) untuk menambah jumlah pejabat jabatan fungsional pengawas pangan District Food Inspector (DFI) yang mumpuni yang bekerja secara optimal dalam pengawasan dan pembinaan terhadap IRTP yang tersedia pada Dinas Kesehatan masingmasing Kabupaten/Kota. Kondisi minimnya Jabatan Fungsional DFI ini sudah bertahun-tahun terjadi, indikasinya tentu dapat kita lihat bahwa setiap Bulan Puasa (Ramadhan) selalu saja tinggi temuan pangan illegal (tidak memiliki SPPIRT) yang dirazia petugas gabungan. Pengadaan DFI melalui DAK tentu diapresiasi agar fasilitasi dan pengawasan terhadap IRTP dan produk yang dihasilkan lebih optimal ke depan.

Berdasarkan hasil identifikasi yang dilakukan terhadap anggaran Dinas Kesehatan pada Tahun 2018, terkait dengan kebijakan Sertifikasi IRTP ini minim sekali. Anggaran yang dialokasikan oleh Dinas Kesehatan untuk Program Pengawasan Obat dan Makanan hanya sebesar Rp. 43.933.320. Besaran anggaran untuk Program Pengawasan Obat dan Makanan ini tentu sangat minim jumlahnya apalagi yang harus dibina dan diawasi tidak hanya IRTP Kopi Bubuk saja di Kabupaten Tanah Datar. Ditambah lagi program ini hanya untuk satu kegiatan yaitu Program Peningkatan Penyidikan dan Penegakkan hukum di bidang obat dan makanan yang bersifat kuratif yang tidak terkait langsung dengan bagaimana memfasilitasi IRTP dalam pengurusan SPP-IRT.

Ketika penulis telaah lebih jauh pada dokumen Rencana Strategis Dinas Kesehatan Kabupaten Tanah Datar pada Tahun 2021, terdapat 2 (dua) program terkait dengan pembinaan dan pengawasan IRTP ini, pertama, Program Peningkatan Pengawasan Obat dan Makanan mempunyai sasaran untuk meningkatkan pengawasan obat dan makanan yang memenuhi syarat di Kabupaten Tanah Datar, dimana indikator capaian sasaran pada Tahun 2021 adalah presentase obat dan makanan yang memenuhi syarat kesehatan sebesar 90\%. Dan, untuk mencapai sasaran tersebut, maka terdapat beberapa kegiatan yang dilakukan oleh Dinas Kesehatan Kabupaten Tanah Datar adalah:

a. Peningkatan Pengawasan dan Keamanan Pangan dan Bahan Berbahaya. Luaran yang akan didapatkan adalah terselenggaranya pengawasan keamanan pangan dan bahan berbahaya. Indikator pencapaian luaran tersebut Tahun 2021 adalah: Persentase pengawasan sarana distribusi pangan dan bahan berbahaya sebesar 100\%.

b. Peningkatan Pemberdayaan Konsumen/Masyarakat di Bidang Obat dan Makanan. Dan, luaran dari kegiatan ini adalah terselenggaranya peningkatan dan pengawaasan obat dan makanan. Indikator pencapaian luaran tersebut pada Tahun 2021 adalah persentase pengawasan sarana distribusi pangan dan bahan berbahaya sebesar $100 \%$.

c. Peningkatan Penyidikan dan Penegakkan Hukum di Bidang Obat dan Makanan. Luaran dari kegiatan ini adalah terseleggaranya penyidikan dan penegakan hukum di bidang obat dan makanan. Sedangkan indikator pencapaian luaran tersebut Tahun 2021 adalah persentase penyidikan dan penengakan hukum di bidang obat dan makanan sebesar $100 \%$.
Program berikutnya adalah Pengawasan dan Pengendalian Kesehatan Makanan yang mempunyai untuk meningkatnya pengawasan dan pengendalian kesehatan makanan. Indikator kegiatanya tersebut adalah tercapainya sasaran hasil pada Tahun 2021 adalah Persentase TPM memenuhi syarat kesehatan 100\%. Dan untuk mencapai sasaran tersebut, maka kegiatan yang akan dilakukan adalah:

a. Pengawasan keamanan dan kesehatan makanan hasil industri;

b. Pengawasan dan pengendalian keamanan dan kesehatan makanan produksi rumah tangga;

c. Pengawasan dan pengendalian keamanan dan kesehatan makanan restauran; dan

d. Monitoring dan evaluasi serta pelaporan.

Jika merunut pada baseline data anggaran yang penulis dapatkan pada Tahun 2018, maka target tersebut cukup realistis mengingat keterbatasan anggaran untuk Program Pengawasan Obat dan Makanan Kabupaten Tanah Datar. Sebagaimana yang diungkap oleh Anderson (2015) bahwa ketika tujuan dinyatakan sebagai hal yang mutlak, sesuatu (program) yang kurang mencapai kesuksesan secara penuh akan ditafsirkan sebagai kegagalan. Akan tetapi untuk memfasilitasi IRTP untuk mendapatkan SPP-IRT masih sangat diperlukan pencarian solusi yang lebih komprehensif terkait kemampuan anggaran dan sumber-sumber pembiayaan lainnya yang lebih mendekatkan pada pencapaian tujuan program (kebijakan). Akan tetapi, dari hasil kajian yang Pemerintah Daerah lebih cenderung untuk membuat kegiatan yang lebih bersifat tindakan pelanggaran yang dilakukan oleh para IRTP Kopi Bubuk disbanding memfasilitasi IRTP dalam pembuatan SPP-IRT. Untuk itu, sebuah kebijakan dalam membuat turunan program, sebagaimana yang diungkap oleh Althaus, Catherin., Birdgman, Peter., \& Davis (2018) bahwa saran kebijakan adalah dasar dari program, jika teorinya cacat maka implementasinya akan gagal.

Pemerintah di masa Pandemi ini, juga sangat memberikan perhatian yang luar biasa terhadap Usaha, Mikro, Kecil, dan Menengah (UMKM). Proporsi anggaran yang dialokasikan untuk menangani Pandemi Covid-19 sektor UKM sebesar Rp 123,46 Triliun pada Tahun Anggaran 2020 (Kemenkeu, 2020) sebagai bagian dari Pemulihan Ekonomi Nasional (PEN). Artinya, bahwa secara politis dukungan terhadap IRTP yang merupakan bagian dari UMKM ini betul-betul menjadi perhatian pemerintah sampai saat Pandemi Covid-19 sekalipun. Akan tetapi, untuk melihat apakah keberpihakan secara politis ini betul-betul dirasakan oleh IRTP Kopi Bubuk di Koto Tuo, hal inilah yang masih menjadi pertanyaan. Dari sisi komitmen politik, pemerintah telah 'melakukan' politiking, karena dalam menghadapi pelbagai tuntutan publik atas formulasi, implementasi, dan evaluasi kebijakan, aktor kebijakan mesti memainkan peranan yang kuat antara lain mengadvokasi kebijakan terkait IRTP ini dalam isu keamanan pangan dan perlindungan konsumen melalui instrument kebijakan dan anggaran. Di sisi yang lain, pada level pemerintah daerah dalam hal ini Kabupaten Tanah Datar, platform Kopi Bubuk Koto Tuo belum menjadi perhatian khusus dikembangkan sebagai icon IRTP khas Kabupaten Tanah Datar untuk dikembangkan secara serius. Pelbagai dokumen perencanaan yang dimiliki dan proporsi anggaran kurang berpihak kepada Kopi Bubuk Koto Tuo ini. Bicara pada level Pemerintahan Nagari Koto Tuo juga tidak berbeda, malahan potensi Kopi Bubuk ini tidak menjadi 
perhatian khusus dalam perencanaan (RPJM Nagari) dan penganggaran (APB Nagari) Desa.

Hasil identifikasi yang penulis lakukan terhadap Dokumen Rencana Pembangunan Jangka Menengah Nagari (RPJM Nagari) dan Rencana Kerja Pemerintah Nagari (RKP Nagari) Nagari Koto Tuo, basis perencanaan yang dilakukan oleh Pemerintah Nagari kurang berorientasi pada potensi yang dimiliki oleh Nagari Koto Tuo itu sendiri. Potensi ekonomi masyarakat yang mayoritas hidup dengan Kopi Bubuk belum menjadi prioritas dalam program dan kegiatan pada Dokumen Perencanaan Nagari Koto Tuo tersebut. Anggaran Pendapatan dan Belanja Nagari (APB Nagari) Tahun Anggaran 2018 Rp. 3.978.003.928 dimana Pendapatan Asli Nagari (PAN) Rp. 1.719.554.000 sedangkan alokasi Belanja pada APB Nagari adalah sebesar 1.451.754.825. Sementara itu, data yang penulis dapatkan dari APB Nagari Koto Tuo Tahun Anggaran 2018 untuk program dan kegiatan yang terkait dengan IRTP Kopi Bubuk terdapat 2 (dua) kegiatan yaitu sosialisasi penyuluhan kesehatan untuk industri kopi dan pelatihan sablon. Anggaran untuk sosialisasi adalah sebesar Rp 6.284.289 sedangkan untuk pelatihan sablon malah lebih besar yaitu sebesar Rp 42.925.922. Minimnya program dan kegiatan yang dalam APB Nagari Koto tersebut adalah wajar, karena memang dokumen perencanaannya tidak berorientasi ke arah pengembangan IRTP Kopi Bubuk di Nagari ini. Sehingga sudah menjadi keniscayaan bahwa permasalahan yang dihadapi oleh IRTP Kopi Bubuk di Koto Tuo dalam pengurusan SPP-IRT menjadi permasalahan tersendiri, karena memang dari sisi perencanaan dan penganggaran kurang berpihak.

Besaran anggaran untuk program dan kegiatan terkait dengan Kopi Bubuk ini juga sangat minim dibandingkan belanja bidang pemberdayaan masyarakat apalagi jika dibandingkan dengan belanja APB Nagari Koto Tuo secara keseluruhan. Program dan kegiatan yang ditawarkan mestinya tidak lagi ke arah sosialisasi bagaimana tata cara produksi tetapi lebih kepada memfasilitasi IRTP agar mampu memenuhi persyaratan, artinya program dan kegiatan yang ditawarkan oleh Pemerintah Nagari kurang sensitif terhadap kebutuhan para IRTP Kopi Bubuk yang ada di Nagari Koto Tuo. Dari uraian tentang kegagalan kebijakan yang diungkap oleh McConnell (2015), penulis menjastifikasi bahwa kegagalan kebijakan yang terjadi dalam SPP-IRT ini adalah kegagalan kebijakan yang dapat ditoleransi. Kekacauan dan ambiguitas dari studi kegagalan kebijakan pemberian SPP-IRT pada IRTP Kopi Bubuk di Koto Tuo dari hasil penelitian ini tentu menciptakan ruang narasi yang akan berbeda jika dikaji dengan perspektif lain, akan tetapi sekali lagi kajian ini membuktikan bahwa proses kebijakan publik tidak berdiri di ruang hampa, terdapat siklus kebijakan yang akan selalu berakhir pada proses evaluasi yang akan kembali pada proses formulasi. Sehingga kebijakan publik kembali ke khittahnya untuk menyelesaikan persoalan-persoalan publik, termasuk dalam kebijakan SPPIRT ini.

\section{KESIMPULAN}

Hasil identifikasi terhadap ragam kebijakan tentang pemberian Sertifikasi Industri Rumah Tangga Pangan (IRTP) dengan kasus yang terjadi dalam pemberian sertifikat IRTP Kopi Bubuk di Nagari Koto Tuo menunjukkan bahwa kegagalan kebijakan yang terjadi termasuk kedalam kriteria kegagalan kebijakan yang dapat ditoleransi (tolerable failure). Hal ini terjadi, Ketika kegagalan dalam implementasi kebijakan yang terjadi masih dapat ditoleransi. Tidak tercapaian tujuan kebijakan yang telah ditetapkan tidak secara fundamental menghalangi pencapaian tujuan. Masih terdapat dukungan terhadap kebijakan pemberian IRTP ini, dan sedikit atau malah tidak ada sama sekali yang menentang dan melakukan kritik terhadap kebijakan yang ada. Hal inilah yang terjadi pada IRTP Kopi Bubuk di Koto Tuo, dimana kesadaran masyarakat terhadap pangan yang layak dikonsumsi masyarakat, aman, dan sehat semakin tinggi, akan tetapi kebijakan gagal hadir dalam menyelesaikan rendahnya Kopi Bubuk Koto Tuo yang tersertifikasi. Hal inilah yang menjadikan tuntutan dari tujuan kebijakan ini adalah untuk terjaminnya keamanan pangan dan perlindungan konsumen. Tanggungjawab pemerintah telah diperlihatkan dengan komitmen lahirnya pelbagai kebijakan terkait keamanan pangan dan perlindungan konsumen. Akan tetapi untuk memperlihatkan komitmen yang tinggi ini, masih lemah dalam pengawasan, pemantauan, dan penegakkan hukum, apalagi belum ada keinginan untuk merubah kebijakan yang lebih meringankan masyarakat IRTP tapi dengan tidak mengurangi fitur keamanan dan kesehatan masyarakat. Karena dari sisi kelengkapan regulasi instrumen kebijakan yang dihasilkan oleh pemerintah sudah cukup lengkap untuk melindungi masyarakat kesehatan masyarakat, perlindungan kepada masyarakat akan pangan yang tidak aman, tidak layak konsumsi, label yang terindikasi menyesatkan dan food fraud, serta berkontribusi positif terhadap pengembangan ekonomi masyarakat ke kondisi yang lebih baik. Kegagalan dalam kebijakan publik dapat juga disebabkan oleh pelbagai kesalahan yang dilakukan oleh aktor kebijakan, diantaranya adalah salah dalam merumuskan masalah publik menjadi masalah kebijakan, lemah dalam memilih alternatif kebijakan, dan bisa juga salah dalam mengimplementasikan sebuah kebijakan maupun kesalahan dalam menyusun instrumen evaluasi kebijakan. Untuk itu, ada baiknya pemerintah memperbaiki kebijakan pemberian SPP-IRT, karena refleksi dari implementasi kebijakan pemberian SPP-IRT yang gagal di Koto Tuo.

\section{REFERENSI}

Althaus, Catherin., Birdgman, Peter., \& Davis, G. (2018). The Australian Policy Handbook: a Practical guide to the policymaking https://doi.org/https://doi.org/10.4324/9781003117940

Ardiati, F. N., \& Puspikawati, S. I. (2019). Evaluasi Pelaksanaan Sertifikasi Produksi Pangan Industri Rumah Tangga (SppIrt) Di Banyuwangi. Journal of Public Health Research and Community Health Development, 2(1), 36. https://doi.org/10.20473/jphrecode.v2il.16251

Boedirochminarni, A., Wachid, M., \& Anggraini, A. (2009). KOTA PROBOLINGGO PROPINSI JAWA TIMUR.

Creswell, J. W. (2013). Research Design Pendekatan Kualitatif, Kuantitatif, dan Mixed. Yogyakarta: Pustaka Pelajar.

Fitriah, M., \& Kusumadinata, A. (2017). Informasi Label Kemasan "Mochibo" Information Of "Mochibo" As A Food Labelling. 8(2), 112-118.

Hermanu, B. (2016). Implementasi Izin Edar Produk PIRT melalui Model Pengembangan Sistem Keamanan Pangan Terpadu. Prosiding Seminar Nasional Multidisiplin Ilmu Unisbank Ke-2 "Kajian Multi Disiplin Ilmu Dalam Pengembangan IPTEKS Untuk Mewujudkan Pembangunan Nasional Semesta Berencana (PNSB) 
Sebagai Upaya Meningkatkan Daya Saing Global, 1945(1), 424-435. Retrieved from file://C:/Users/User/Downloads/4225-Article Text-27621-10-20160812.pdf

Hogwood, Brian W., \& Gunn, L. A. (1986). Policy Analysis for the Real World. Oxford: University Press.

Hudson, B., Hunter, D., \& Peckham, S. (2019). Policy failure and the policy-implementation gap: can policy support programs help? Policy Design and Practice, 2(1), 1-14. https://doi.org/10.1080/25741292.2018.1540378

Koeswara, Hendri., Aromatica, Desna., Yulivestra, Malse., Kabullah. Muhammad Ichsan., Liesmana., Roza \& Hidayat, Enggi. (2020). Collaborative Governance Dalam Kebijakan Sertifikasi Produksi Pangan Industri Rumah Tangga Kopi Bubuk Koto Tuo. Jurnal Administrasi dan Kebijakan Publik, 5(2), 193-207. https://doi.org/10.25077/jakp

Komala, I'ik Santi., Widajanti, Laksi., \& Pangestuti, D. R. (2017). Cara Produksi Pangan Yang Baik Untuk Industri Rumah Tangga (Cppb-Irt) Perusahaan Tahu Putih Kabupaten Semarang Tahun 2017. Jurnal Kesehatan Masyarakat (e-Journal), 5(4), 690-697.

Kurniawan, D. A., \& Astuti, R. Y. (2018). Khadimul ummah. Khadimul Ummah: Journal of Social Dedication, 1(2), 93101. Retrieved from https:/ejournal.unida.gontor.ac.id/index.php/khadimulum $\mathrm{mah} /$ article/view/2493/1512

Lindblom, C. (1986). The Policy Making Process. Englewood Cliff: Prentice Hall.

McConnell, A. (2015). What is policy failure? A primer to help navigate the maze. Public Policy and Administration, 30(34), 221-242. https://doi.org/10.1177/0952076714565416

Murwadji, T., \& Saraswati, A. (2019). INCREASED CAPACITY BUSINESS SMALL MICRO ENTERPRISES THROUGH THE CERTIFICATION OF kesejahteraan rakyat adalah tanggung jawab masyarakat dan tanggung jawab tersebut (the walfare state). 2 Indonesia merupakan negara hukum yang bercirikan negara kesejahtera. (21), 1331.

Owen, A., Defiana, Tjota, H., Handoko, V., Stefhanie, Pakpahan, N., \& Kiyat, W. El. (2020). Evaluasi Sanitasi Pangan pada Produksi Brownies Skala Industri (Studi Kasus di UMKM Libby Brownies). Jurnal Teknologi Pengolahan Pangan, 2(1), 21-27. $\quad$ Retrieved from http://jurnal.utu.ac.id/jtpp/article/view/2174/1642

Purba, D. F., Nuraida, L., \& Koswara, S. (2013). Efektivitas Program Peningkatan Mutu Dan Keamanan Pangan Industri Rumah Tangga Pangan ( Irtp ) Di Kabupaten Cianjur Effectiveness Assessment of Food Quality and Safety Inspection Program for Household Food Industry ( HFI ) in Cianjur District. Jurnal Standardisasi, 16(2), 103112.

Putri, Rr. Asri Ismaya., Rohayati, Yati., \& Aisha, A. N. (2015). Evaluasi Sanitasi Pangan pada Brownies Skala Industi (Studi Kasus di UMKM Libby Brownies). Jurnal Rekayasa Sistem \& Industri, 2(3), 17-24. https://doi.org/jrsi.sie.telkomuniversity.ac.id > index > JRSI

Rezki, R. (2020). Evaluasi Penerapan CPPB-IRT Industri Rumah Tangga Pangan ( IRTP ) Minuman Tradisional di Desa Mekarharja ( Evaluation of the Application of CPPBIRT in Traditional Beverages Home Industry in Mekarharja Village ). Jurnal Pusat Inovasi Masyarakat, 2(1), 28-33.
Rohmah, F., Domai, T., Publik, J. A., Administrasi, F. I., \& Brawijaya, U. (2015). Strategi Pemerintah Daerah dalam Pemberdayaan Usaha Mikro Kecil Menengah olahan mangga ( Studi pada Sentra Olahan Mangga Desa Banjarsari , Kecamatan Sumberasih , Kabupaten Probolinggo ). Jurnal Administrasi Publik (JAP), 3(12), 2040-2044.

Rosenbloom, David H., Kravchuk, Robert S., \& Clerkin, R. M. (2015). Public Administration Understanding Management, Politics, and Law in the Public Sector. New York: McGrawHill Education.

Sarfiah, S., Atmaja, H., \& Verawati, D. (2019). UMKM Sebagai Pilar Membangun Ekonomi Bangsa. Jurnal REP (Riset Ekonomi Pembangunan), 4(2), 1-189. https://doi.org/10.31002/rep.v4i2.1952

Yin, R. K. (2008). Case Study Research: Design and Methods (Applied Social Research Methods). Illinois: Sage Publications, Inc. 